\title{
Erratum to: A Semianalytical Thermal Model for Friction Stir Welding
}

P. FERRO and F. BONOLLO

DOI: $10.1007 / \mathrm{s} 11661-009-0170-1$

(C) The Minerals, Metals \& Materials Society and ASM International 2010

\section{Erratum to: METALLURGICAL AND MATERIALS \\ TRANSACTIONS A, Vol. 41A, No. 2, pages 440-49 \\ DOI: 10.1007/s11661-009-0104-y}

THE correct title of this article is "A Semianalytical Thermal Model for Friction Stir Welding."

P. FERRO, Ph.D. Researcher, and F. BONOLLO, Professor, are with the Department of Management and Engineering, University of

Padova, Stradella San Nicola 3 - 36100 Vicenza, Italy. Contact e-mail: ferro@gest.unipd.it

The online version of the original article can be found under doi: 10.1007/s11661-009-0104-y.

Article published online January 8, 2010 